\title{
The Economic Model of Optimal Allocation of Financial Health Resources
}

\author{
${ }^{1}$ Liliana A. Sosunova, ${ }^{2}$ Sergey V. Noskov, ${ }^{3}$ Liliya H. Mukhametzyanova, ${ }^{4}$ Eugene P. Fomin \\ Liliana A. Sosunova is PhD, Professor of Samara State University of Economics, Samara, Russia, 443090, \\ Samara, Sovetskoi Armii Street, 141. \\ Sergey V. Noskov is PhD, Professor of Samara State University of Economics, Samara, Russia. \\ Liliya H. Mukhametzyanova is PhD, Associate Professor of Samara State University of Economics, 443090, \\ Samara, Sovetskoi Armii Street, 141. \\ Eugene P. Fomin is PhD, Doctor of Economic Sciences, Professor of Samara State Economic University, \\ 443090, Samara, Sovetskoi Armii Street, 141.

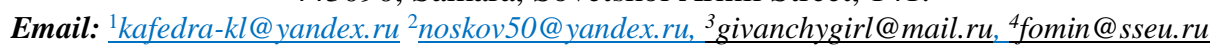

\section{Received: $2^{\text {th }}$ Feb 2018, Accepted $17^{\text {th }}$ March 18, Published: $30^{\text {th }}$ April 2018}

\begin{abstract}
The relevance of the analyzed issue is caused by the need to improve the efficiency of limited financial resources of the regional public health service for its development programs, the growth of quality and accessibility of medical services to the population. The purpose of the article is to develop the economic-mathematical model that can allocate regional financial resources by health development subprograms using the example of the Samara region of the Russian Federation. The main results: to represent the performance decline of increased spending on the regional public health service in terms of the life expectancy of the region's population; to conduct the optimal allocation of financial resources by health development subprograms of the Samara region by the maximum life expectancy of the population (utility). The contents of the article can be used to develop health development programs and plans.
\end{abstract}

Keywords: Public Health Service, Medical Statistics, Modeling, Optimization, Regression Equations, Financial Resources.

\section{Introduction}

The regional health development program for 20142018 has set goals, defined tasks and activities to improve the accessibility, quality and effectiveness of health services to the population of the Samara region. It also provides financial support for the implementation of the health development program in the amount of 464.2 billion rubles from the consolidated budget, territorial fund of obligatory medical insurance and legal persons (The Ministry of Health of the Samara region, 2013) [1].

The main implementation problem of health development programs is the performance decline of production factors of medical services and allocation of financial resources. The basis of the performance decline is the fundamental principle of diminishing returns of used resources. A low performance of investment in human resources of the health service is illustrated by research of their funding by the Global Fund in 138 countries (Bowser et al., 2014) [2]. The European Health Association and a number of authors note decreasing health performance results under health spending growth (Peiró and Maynard', 2015) [3].

An important target indicator of the health development in any country, according to many researchers, is the indicator of the life expectancy at birth, and its change is influenced by several groups of factors. Other studies have examined such subgoals of the health development as the increase in the health performance, the availability of public health services and sustainability of the health system (Bernal-Delgado et al., 2015) [4]. As an interim subgoal of the health development can be considered the growth in the quality of medical services and the increase of patient satisfaction with hospitals (Rannan-Eliya et al., 2015) [5].

The determinants of the public health service include a group of development factors of the health sector and a group of social factors. The last group of factors includes economic, environmental, social, political and informational-technological factors (World Health Organization. Regional office for Europe, 2012) [6]. At the same time some determinants of the public health service belong to the industry and community groups of factors. For example, a group of social factors include the equitable allocation of financial resources in the health sector (Adler-Milstein et al., 2014) [7], industry factors of the public health service include - the use of medical information and management systems in radiology departments of hospitals, traumatology and cardiology (Anselmi et al., 2015) [8]. Some studies have highlighted meso-level factors influencing the priorities of hospitals in providing health services, which include the availability of resources, financing mechanisms, organizational culture and leadership, staff interests and power relations (Barasa et al., 2015) [9]. The modern factor in achieving health targets is the use 
Helix Vol. 8(3):3432-3440

of social media for communication and training the majority of European health organizations (Fast et al., 2015) [10].

\section{Methods}

At each stage of research the authors used statistical, expert and mathematical and statistical methods and models, which are relevant to issues solved. The structure of research was determined by the logical sequence of stages: to choose a socially significant economic activity as a target of health research in the region, to select resource factors of the health development and assess their impact on the target indicator to increase the life expectancy, to assess the dependence of the life expectancy on changes in health spending as the dominant factor using mathematical and statistical modeling, to use the obtained regression dependence in optimizing the allocation structure of financial resources by health development subprograms of the Samara region by maximizing the average life expectancy indicator of the population.

\section{The Representativeness of the Research Object} The Samara region of the Russian Federation is included in the Volga Federal District, its population is 3.3 million people, $81 \%$ of them are urban population. According to the rating agency "RIA Rating" the Samara region took the 6th place in 2013 by a combined rating of the socio-economic status of subjects of the Russian Federation. This rating includes the assessment of the scale of economies, its effectiveness, the development level of the public sector and social spheres (The rating of socioeconomic status of subjects of the Russian Federation following the results of 2013, 2014) [11].

In terms of the quality of life the Samara region took the 13th place among 71 subjects of the Russian Federation in 2014, in terms of demographics - the 33th place, in terms of health and education indicators - the 35th place. Health resources of the region currently include 133 health care institutions, including 61 hospitals, 27 health centers, 15 dispensaries, 30 other health care organizations. As of 01.01.2015, under the Ministry of Health of the Samara region, about 36 thousand medical workers 3433 were employed in the health sector: about 12 thousand doctors, more than 24 thousand midranking medical staff. All of this allows us to consider the public health service of the Samara region as a typical representative of the majority of regional health sectors in the Russian Federation, and the probability, that research results on optimizing the use of financial health resources can repeat, is rather high.

\section{Result-oriented and Assessment Methods of Intermediate and Final Research Results}

The authors used heuristic methods of quality sorting of factors that influence the life expectancy of the population of the Samara region, as well as mathematical and statistical methods of correlation analysis and image interpretation methods of identified relationship indicators of the public health service for 2006-2014. The regression analysis was used to establish mathematical and statistical dependence of the life expectancy of the population of the Samara region on changes of region's spending on the public health service, to define mathematical-statistical characteristics of the equation of nonlinear regression, as well as indicators of absolute elasticity.

While assessing the target - to increase the life expectancy of the population as a result of health development subprograms of the Samara region, the authors used the expert method with the concurrence definition of expert assessments according to their coefficient of variation. The optimal assessment of the region's financial health resources of its development subprograms for 2013-2020 was determined on the basis of the nonlinear problem solution of computer programming.

\section{Results}

The decomposition of major health development determinants allows selecting specific social, economic, cultural intrapersonal factors for specific populations, such as men and women (Niedzwiedz et al., 2014) [12], adolescents (Velderman et al. 2015) [13], immigrants (Diaz et al., 2015) [14], homeless (Slockers et al., 2015) [15] and rural citizens (Borda-Olivas et al., 2012) [16]. 
Helix Vol. 8(3):3432-3440

The main factors, determining the health development of the Samara region and the implementation of regional programs upon targets of the life expectancy growth and mortality decline from all causes, are the capacity of outpatient organizations, medical service density and spending on the public health service from all sources of financing. The choice of these health development factors is carried out on the basis of the qualitative analysis of resources of medical organizations and some of them are justified as inputs of production function (Mateus et al. 2015) [17]. The spending changes on the public health service and investment in the health care sector have an impact on the public health, and this fact is recognized by many scientists (Schrecker \& Milne, 2015; Smith \& Eltanani, 2015) [18-19]. As targets for the life expectancy and mortality are close to zero correlation, the life expectancy at birth is the performance factor indicator. Initial data for the multifactor economic and mathematical modeling of the life expectancy dependence of the Samara region are presented in Table 1.

\section{Table 1. Baseline Data of Profit-and-Lost and Factor Values}

\begin{tabular}{|c|c|c|c|c|}
\hline \multirow{2}{*}{ Years } & \multicolumn{3}{|c|}{ Indicators } \\
\cline { 2 - 5 } & Life expectancy, years & $\begin{array}{c}\text { Capacity of } \\
\text { ambulatory-care } \\
\text { clinics, thousand office } \\
\text { visits / shift }\end{array}$ & $\begin{array}{c}\text { The number of } \\
\text { doctors per 10 } \\
\text { thousand people, } \\
\text { pers. }\end{array}$ & $\begin{array}{c}\text { Spending on the public } \\
\text { health service, billion } \\
\text { rubles }\end{array}$ \\
\cline { 2 - 5 } & $\mathrm{Y}$ & $\mathrm{X}_{1}$ & $\mathrm{X}_{2}$ & $\mathrm{X}_{3}$ \\
\hline 2006 & 66,6 & 61,3 & 48,5 & 13,7 \\
\hline 2007 & 67,2 & 69,0 & 49,9 & 15,2 \\
\hline 2008 & 67,5 & 68,4 & 48,5 & 18,8 \\
\hline 2009 & 68,2 & 69,9 & 49,2 & 19,7 \\
\hline 2010 & 68,6 & 76,8 & 4,7 & 20,4 \\
\hline 2011 & 69,0 & 82,4 & 47,3 & 21,7 \\
\hline 2012 & 69,7 & 79,6 & 47,7 & 29,9 \\
\hline 2013 & 69,4 & 84,3 & 47,6 & 31,8 \\
\hline 2014 & 69,7 & 85,0 & \\
\hline
\end{tabular}

Source: Federal state statistics service. Available at: http://www.gks.ru/wps/wcm/connect/rosstat main/ rosstat/ru/ statistics/population/demography/\#

As a result of the pre-mathematical and statistical analysis, the authors received pair correlation coefficients characterizing the close relationship between selected indicators with the assumption of a linear relationship between them (Table 2).

Table 2. Matrix of Pair Correlation Coefficients

\begin{tabular}{|c|c|c|c|c|}
\hline & $\mathrm{Y}$ & $\mathrm{X}_{1}$ & $\mathrm{X}_{2}$ & $\mathrm{X}_{3}$ \\
\hline $\mathrm{Y}$ & & 0,947 & $-0,586$ & 0,845 \\
\hline
\end{tabular}


Helix Vol. 8(3):3432-3440

\begin{tabular}{|c|c|c|c|c|}
\hline$X_{1}$ & & & $-0,467$ & 0,872 \\
\hline$X_{2}$ & & & & $-0,593$ \\
\hline$X_{3}$ & & & & \\
\hline
\end{tabular}

Source: It is calculated by authors according to the data in Table 1 .

The values of pair correlation coefficients suggest the following conclusions: first, the correlation coefficient between the life expectancy at birth (Y) and the number of doctors per 10 thousand people of the Samara region $\left(\mathrm{X}_{2}\right)$, equal to -0.586 , is an inverse relationship between indicators. This is achieved by previously saturating amount of doctors of outpatient organizations, that is, patterns of the performance decline in the use of human resources in the public health service. So, in developed countries there are
33,8 doctors for 10 thousand people in Austria, in France and Germany - 33,7 doctors, in Sweden - only 32,8 doctors. A low performance of investment in human resources of the public health service is proved by research of their financing by the Global Fund in 138 countries (Bowser et al. 2014) [2]. Declining performance growth in the number of doctors of the public health service of the Samara region in terms of the life expectancy is presented in Figure 1.

\section{Figure 1. Empirical and Theoretical Dependence of the Life Expectancy on Changes in the Number of} Doctors

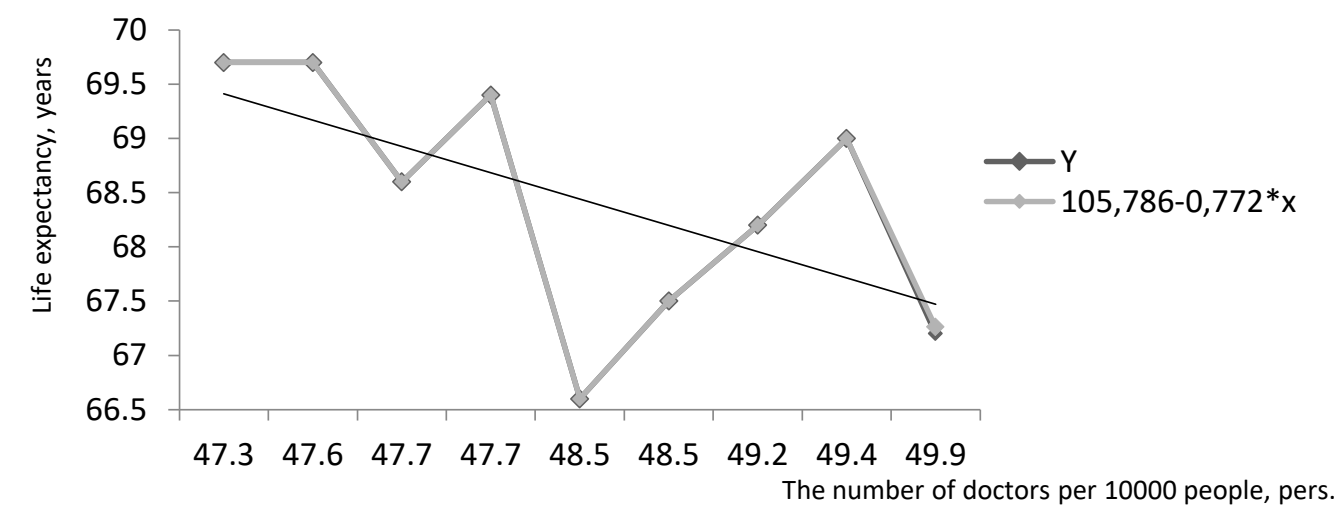

Source: It is made by authors according to the data in Table 1.

The reduced life expectancy of the population during the period of 2006-2014 is constant and equal to 0.772 of the year with an increase in the number of doctors of 1 person a year. The combination of health resources is the optimal combination of such components, as the number of doctors, the provision of drugs and medical devices, rational nutrition of patients and high-tech medical equipment. Any deviation from the optimal combination of basic health resources reduces its effectiveness.
Second, the correlation coefficient between the capacity of outpatient organizations $\left(\mathrm{X}_{1}\right)$ and the health spending of the Samara region $\left(\mathrm{X}_{3}\right)$ is 0.872 , and it requires excluding one of the factor indicators from consideration. Indeed, the capacity of public health organizations is largely determined by their financing, and this factor indicator is primary relative to capacity.

Thus, the main factor indicator, which determines the health performance in terms of the life expectancy of 
Helix Vol. 8(3):3432-3440

the region's population, is spending on the public health service. The further mathematical and statistical analysis determined the theoretical dependence of the life expectancy of the region's population (Y) on changes in health spending $(\mathrm{X})$ according to Table 1:

$$
\mathrm{Y}=3.606 * \ln (\mathrm{X})+57.61
$$

Empirical and theoretical dependence of the life expectancy of the region's population on health spending is presented in Figure 2.

\section{Figure 2. Empirical and Theoretical Dependence of the Life Expectancy on Changes in Health Spending}

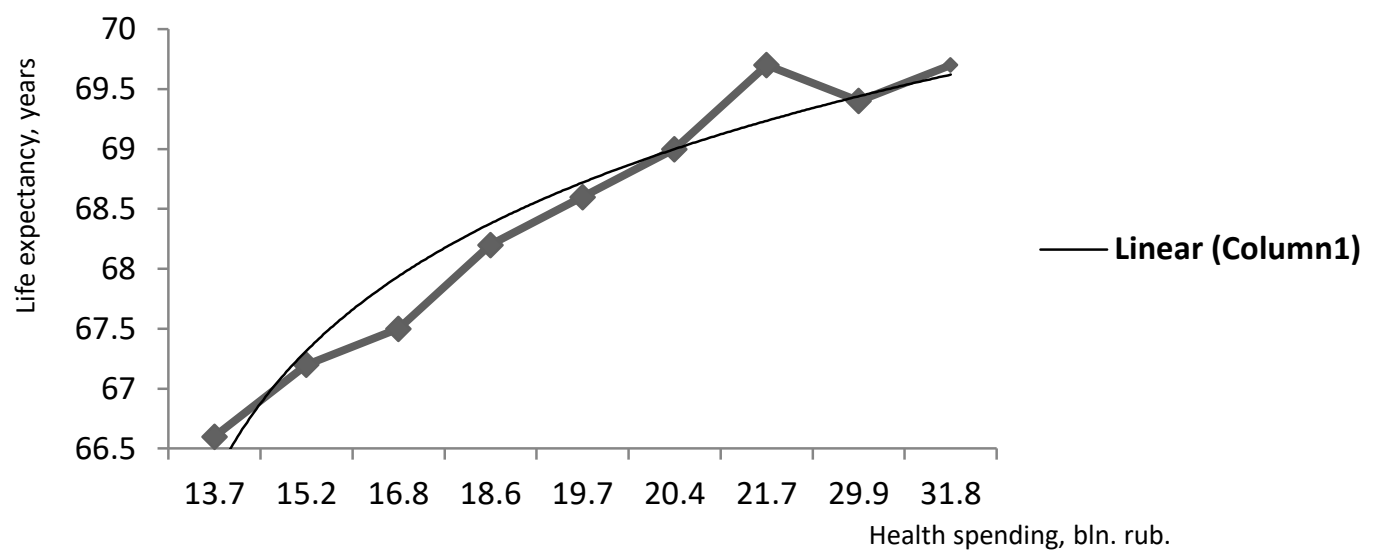

Source: It is made by authors according to the data in Table 1.

-Mathematical and statistical characteristics of the equation of nonlinear regression:

- The correlation index and determination coefficient are equal to 0.897 and 0.805 , respectively;

- The mean approx error is $0.58 \%$;

- F-test is 33.03, which exceeds its table value to 5.59 under the significance level of 0.05 .

The dependence graph of the life expectancy of the population of the Samara region on changes in health spending, as well as the calculation of values of its first derivative in health spending, that are equal to 15,20 , 25 and 30 billion rubles, indicate their declining performance:

$$
\frac{d A(t)}{d(15)}=0.240, \quad \frac{d A(t)}{d(20)}=0.180, \quad \frac{d A(t)}{d(25)}=0.144
$$

Therefore, in contrast to the impact of increasing number of doctors of outpatient organizations in the region on the life expectancy of its population, which 3436 decreases at a constant rate - equal to 0.772 a year, an increase in the number of doctors - 1 doctor a year, the impact of the increasing health spending on the life expectancy of the population by 1 billion rubles a year is growing with a decreasing rate. The declining health performance results under health spending growth are noted, for example, by the European Health Association and some authors (Peiró \& Maynard 2015) [3].

Thus, a simple financing rising in health spending of the Samara region without optimizing the structure of its allocation by types of health care, intra-allocation, $d A(t)$ cation according to terms, types of diseases, the structupel 29 future fees (Ro)r the provision of medical $d$ (3a)e do not guarantee that health care facilities and measures to modernize these facilities will achieve their targets.

The regional health development program involves, in particular, an increase in the life expectancy at birth to 
Helix Vol. 8(3):3432-3440

74.0 years in 2020 as one of its target indicators. The authors established the funding program in general and its individual subprograms for 2014-2018. The Ministry of Health of the Samara region allocated funds to implement programs in the total amount of 464.23 billion rubles.

The authors developed the optimal allocation of financial health resources by subprograms of the regional program "Health development of the Samara region for 2014-2018". The economic- mathematical model of the optimal allocation of financial resources by health development subprograms included expert assessment - to assess the achievement of the target to increase the life expectancy of the population of each subprogram under its financing in volumes established for 2014-2018.

The assessment of the achievement of the target of each subprogram or its utility was performed according to 10-point scale by four experts with the following calculation of the achievement of the target to increase the life expectancy in relative units. The consistency of expert evaluations as random values was set by the coefficient of variation, the value of which did not exceed $15 \%$.

The allocation of financial resources by health development subprograms, the assessment of the utility of each of them according to the achievement of the target to increase the life expectancy and the overall usefulness definition of each of subprograms are shown in Table 3.

Table 3. Utility Assessment of Allocation of Financial Resources for Health Development Subprograms

\begin{tabular}{|c|c|c|c|}
\hline Name of subprogram & $\begin{array}{l}\text { Amount of funding } \\
\text { billion rubles. }\end{array}$ & Utility ratio & $\begin{array}{l}\text { Total utility } \begin{array}{r}\text { of } \\
\text { subprogram, billion } \\
\text { rubles. }\end{array} \\
\end{array}$ \\
\hline $\begin{array}{l}\text { 1. Prevention of diseases and promotion } \\
\text { of healthy lifestyles. Development of primary } \\
\text { health care }\end{array}$ & 75,49 & 0,143 & 10,80 \\
\hline $\begin{array}{l}\text { 2.Improving the provision of specialized, } \\
\text { including high-tech, health care, and } \\
\text { ambulance }\end{array}$ & 119,27 & 0,204 & 24,33 \\
\hline $\begin{array}{l}\text { 3.The development of public-private } \\
\text { partnership }\end{array}$ & 10,62 & 0,061 & 0,65 \\
\hline 4. Maternal and child health & 70,26 & 0,184 & 12,93 \\
\hline $\begin{array}{l}\text { 5. The development of medical rehabilitation } \\
\text { and sanatorium treatment, including children }\end{array}$ & 14,05 & 0,082 & 1,15 \\
\hline 6. Palliative care, including children & 0,35 & 0,041 & 0,01 \\
\hline 7. Staffing of the health system & 130,23 & 0,082 & 10,68 \\
\hline $\begin{array}{l}\text { 8. Improving drug supply systems, including } \\
\text { outpatients }\end{array}$ & 39,03 & 0,143 & 5,58 \\
\hline 9. IT development in the public health service & 4,93 & 0,060 & 0,30 \\
\hline Total & 464,23 & 1,000 & 66,43 \\
\hline
\end{tabular}

The optimal allocation of financial resources by health

development subprogram of the Samara region can be

Copyright @ 2018 Helix ISSN 2319 - 5592 (Online) 
Helix Vol. 8(3):3432-3440

set on the basis of economic and mathematical modeling.

The economic-mathematical model of the optimal allocation of financial resources in the amount of 494.23 billion rubles for 2014-2018 by health development subprograms include:

- The objective function $\mathrm{f}(\mathrm{x})$, established earlier by the results of the correlation and regression analysis;

- The transposed matrix of utility values of each subprogram of the health development (a);

- The transposed matrix of values of the initial allocation of funds by subprograms (s);

- The limit on the total amount of financial resources (g);

- The matrix of values of the optimal allocation of funds by subprograms (x0);

- The maximum utility of health development subprograms $\mathrm{f}(\mathrm{x} 0)$.

The problem solution of the optimal allocation of financial resources by health development subprograms of the Samara region is the following:

$$
\begin{aligned}
& a:=\left(\begin{array}{lllllllll}
0.143 & 0.204 & 0.061 & 0.184 & 0.082 & 0.041 & 0.082 & 0.143 & 0.060
\end{array}\right)^{T} \\
& x:=\left(\begin{array}{lllllllll}
75.49 & 119.27 & 10.62 & 70.26 & 14.05 & 0.35 & 130.23 & 39.03 & 4.93
\end{array}\right)^{T} \\
& g:=464.23 \quad f(x):=a \cdot(3.606 \ln (x)+57.6)
\end{aligned}
$$

Given

$\sum x \leq g \quad x 0: \operatorname{Maximize}(f, x)$

$x 0=\left(\begin{array}{lllllllll}68.335 & 96.355 & 28.345 & 88.255 & 39.609 & 8.812 & 39.066 & 68.15 & 27.303\end{array}\right)$

$f(x 0)=72.233$

The growth of health development subprograms of the Samara region or the achievement of the target to increase the life expectancy as a result of the optimal allocation of financial resources will be $8.7 \%$ :

$\frac{72.233-66.43}{66.43} \cdot 100 \%=8.7 \%$.

\section{Discussion}

This research has made a number of hypotheses, used a variety of research methods and using them the authors obtained results that may be the subject of discussion.
Firstly, the list of factors identified on the basis of the qualitative analysis, that affect the life expectancy of the population of the region, can be supplemented by such factors as rising health spending on high-tech medical equipment, an increase in the average salary of medical staff and quality improvement of services provided. Secondly, the assessment of the relationship closeness between performance (the life expectancy of the population of the region) and factor (health resources) indicators on the basis of pair correlation coefficients was carried out under the condition of the linear dependence between them. However, a more rigorous analysis of this relationship shows their nonlinear dependence, for example, between the duration the life expectancy and health spending. Third, the expert assessment of the achievement of the target to increase the life expectancy of the population of each region's health development subprogram or other utility can be carried out by mathematical and statistical methods.

\section{Conclusion}

The main target indicator of the state and development of the country's public health service, or the region's is the expectancy of life at birth. Many factors can change this indicator, among which such resource factors as the capacity of ambulance-care clinics, the number of doctors and health spending. The carried mathematical and statistical analysis showed the declining performance growth in the number of doctors in the public health service of the Samara region in terms of the life expectancy. This fact is explained by non-optimal combination of influencing factors.

The mathematical and statistical analysis also revealed a decreasing life expectancy rate of the population in the region by increasing health spending. This fact is explained, in particular, by non-optimal allocation of financial resources by health development subprograms of the region. The optimal allocation of health resources based on the formulation and solution of linear programming problems will increase the life expectancy in the region by $8.7 \%$.

The further research to optimize the allocation of financial health resources may be directed to optimize the allocation of financial resources by clusterscustomers on the basis of fractal-cluster relations and 
Helix Vol. 8(3):3432-3440

major resource components of the health system.

\section{References}

1. Adler-Milstein, J., Kvedar, J., Bates, D.W. (2015). Telehealth among US hospitals: several factors, including state reimbursement and licensure policies, influence adoption. Health Affairs, 33(2). Available at: http://www2.itif.org/2014-unlocking-potentialphysician-patient-telehealth.pdf

2. Anselmi, L., Lagarde, M. \& Hanson, K. (2015). Equity in the allocation of public sector financial resources in low- and middle-income countries: a systematic literature review. Health Policy Plan, 30(4), pp. 528-545. doi:10.1093/heapol/czu034.

3. Barasa, E.W., Molyneux, S., English, M., Cleary, S. (2015). Setting healthcare priorities in hospitals: a review of empirical studies. Health Policy Plan, 30(3). pp. 386396. doi:10.1093/heapol/czu010.

4. Bernal-Delgado, E., Christiansen, T., Bloor, K., Mateus, C., Yazbeck, A.M., Munck, J., Bremner, J. (2015). ECHO: health care performance assessment in several European health systems. Eur J Public Health, 25 (suppl 1), 37. DOI:http://dx.doi.org/10.1093/eurpub/cku219.

5. Borda-Olivas, A., Fernández-Navarro, P., OteroGarcía, L., Sanz-Barbero, B. (2013). Rurality and avoidable hospitalization in a Spanish region with high population dispersion. Eur $J$ Public Health, 23(6), pp. 946-951 DOI: http://dx.doi.org/10.1093/eurpub/cks163. First published online: 26 November 2012.

6. Bowser, D., Sparkes, S.P., Mitchell, A., Bossert, T.J., Bärnighausen. T., Gedik, G., Atun, R. (2014). Editor's Choice: Global Fund investments in human resources for health: innovation and missed opportunities for health systems strengthening. Health Policy Plan, 29(8), pp. 986997. doi:10.1093/heapol/czt080.

7. Diaz, E., Calderón-Larrañaga, A., PradoTorres, A., Poblador-Plou, B., Gimeno-Feliu, L.A. (2015). How do immigrants use primary health care services? A register-based study in Norway. Eur J Public Health, 25(1), 7278. DOI:http://dx.doi.org/10.1093/eurpub/cku12 3. First published online: 1 August 2014 .
8. Fast, I., Sorensen, K., Brand, H., Suggs, L.S. (2015). Social Media for Public Health: An Exploratory Policy Analysis. Eur J Public Health, 25(1), pp. 162-166. DOI:http://dx.doi.org/ 10.1093/eurpub/cku080.

9. Federal state statistics service. (2015). The official statistics. Population. Demography. Available at:http://www.gks.ru/wps/wcm/connec t/rosstat_main/ rosstat/ru/ statistics/population/demography/\#

10. Mateus, C., Joaquim, I., Nunes, C. (2015). Measuring hospital efficiency comparing four European countries. Eur J Public Health, 25(suppl 1), pp. 52$58 . \quad$ DOI:http://dx.doi.org/ 10.1093/eurpub/cku222.

11. Niedzwiedz, C.L., Katikireddi, S.V., Pell, J.P., Mitchell, R. (2014). Socioeconomic inequalities in the quality of life of older Europeans in different welfare regimes. Eur $J$ Public Health, 24(3), pp. 364-370 DOI: http://dx.doi.org/ 10.1093/eurpub/cku017.

12. Peiró, S. \& Maynard, A. (2015). Variations in health care delivery within the European Union. Eur J Public Health, 25(suppl. 1), pp. 12. DOI:http://dx.doi.org/ 10.1093/eurpub/cku223.

13. Rannan-Eliya, R.P., Nilmini, W., Liyanage, I.K., Dalpatadu, S., Alwis, de S., Amarasinghe, S., Shanthikumar, S. (2015). Quality of inpatient care in public and private hospitals in Sri Lanka. Health Policy Plan, 30 (suppl. 1), pp. 146158.doi: 10.1093/heapol/czu062 This article appears in: Symposium on the Private Sector in Health: Sydney 2013.

14. Schrecker, T., Milne, E. (2015). Health and politics for 2015 and beyond. J Public Health, 37(1), pp. 12 doi:10.1093/pubmed/fdu112.

15. Slockers, M.T., Nusselder, W.J., Looman, C.W.N., Slockers, C.J.T., Krol, L., Beeck, van E.F. (2015). The effect of local policy actions on mortality among homeless people: a before-after study. Eur J Public Health, 25(2), pp. 
Helix Vol. 8(3):3432-3440

290-292. DOI:http://dx.doi.org/10.1093/eurpub/ cku155.

16. Smith, K.E., Eltanani, M.K. (2015). Editor's Choice: What kinds of policies to reduce health inequalities in the UK do researchers support? $J$ Public Health, 37(1), pp. 617 doi:10.1093/pubmed/fdu057.

17. The Ministry of Health of the Samara region,2013. About approval of the state program of the Samara region "Health development of the Samara region" for 2014-2018. Resolution of the government of the Samara region dated 27.11.2013 No. 674. Available at: http://minzdrav.samregion.ru/documents/postano vleniya-resheniyapolozheniya/document491.html.

18. The rating of socio-economic status of subjects of the Russian Federation following the results of 2013. Available at: http://riarating.ru/infografika/ 20140523/610617608.html

19. Velderman, M.K., Dusseldorp, E., Nieuwenhuijzen, M.V., Junger, M., Paulussen, Theo G. W. M., Reijneveld,S.A. (2015). Cultural, social and intrapersonal factors associated with clusters of co-occurring health-related behaviours among adolescents. Eur J Public Health, 25(1),pp. 3137. DOI: http://dx.doi.org/10.1093/ eurpub/cku051.

20. World Health Organization. Regional office for Europe. Malta (10-13 September 2012). Health 2020. Health 2020: a European policy framework supporting action across government and society for health and wellbeing. Available at: http://www.euro.who.int/ data/assets/pdf_file/0009/169803/RC62wd09-

Eng.pdf 